\title{
Efek Stres Puasa terhadap Ketebalan Epitel dan Diameter Tubulus Seminiferus Rattus norvegicus
}

\author{
Fasting Effect on Epithelium Height and Seminiferous Tubules Diameter of Rattus norvegicus
}

\author{
Nila Munaya ${ }^{1^{*}}$, Ageng Brahmadhi ${ }^{2}$, Yuhantoro Budi Handoyo Sakti ${ }^{3}$ \\ ${ }^{1}$ Program Studi Pendidikan Dokter, Fakultas Kedokteran, Universitas Muhamadiyah Purwokerto \\ ${ }^{2}$ Laboratorium Histologi, Fakultas Kedokteran, Universitas Muhammadiyah Purwokerto \\ ${ }^{3}$ Bagian Bedah, Rumah Sakit Islam Purwokerto
}

DATA NASKAH:

Masuk: 26 Nov 2017

Direviu: 02 Des 2017

Direvisi: 16 Desr 2017

Diterima: 30 Des 2017

*KORESPONDENSI: nilamunaya@gmail.com

DOI:

10.18196/mm.180107

TIPE ARTIKEL:

Penelitian

\begin{abstract}
Abstrak: Puasa merupakan stres biologi yang dapat menyebabkan stres oksidatif. Stres oksidatif menyebabkan penurunan spermatogenesis dan berat testis yang terkait dengan tubulus seminiferus. Tujuan penelitian ini untuk mengetahui efek puasa terhadap berkurangnya ketebalan epitel dan diameter tubulus seminiferus tikus. Penelitian ini merupakan penelitian analitik eksperimental laboratorium dengan post-test only with control group design. Subjek penelitian adalah tikus putih jantan galur wistar sebanyak 30 ekor dengan berat badan 150-300 g, dan umur 2-4 bulan. Tikus dibagi secara acak menjadi 3 kelompok, yaitu kelompok kontrol, kelompok perlakuan puasa $10 \mathrm{jam}$, dan kelompok perlakuan puasa $12 \mathrm{jam}$. Puasa dilakukan selama 14 hari. Subjek penelitian selanjutnya diterminasi, dieksisi dan ditimbang testisnya, kemudian dilakukan preparasi histologi dengan pewarnaan HE. Selanjutnya dianalisis secara histomorfometrik menggunakan perangkat lunak Image J. Data dianalisis menggunakan MANOVA diikuti uji LSD. Hasil penelitian menunjukkan ketebalan epitel dan diameter tubulus seminiferus pada kelompok perlakuan lebih rendah secara signifikan dibandingkan dengan kelompok kontrol $(p<0,05)$. Namun, ketebalan epitel dan diameter tubulus seminiferus antara kelompok perlakuan puasa 10 jam dan 12 jam tidak terdapat perbedaan signifikan $(p>0,05)$. Disimpulkan bahwa terdapat efek puasa terhadap berkurangnya ketebalan epitel dan diameter tubulus seminiferus tikus.
\end{abstract}

Kata kunci: Stres; Puasa; Ketebalan Epitel; Diameter Tubulus Seminiferus; Rattus Norvegicus

\footnotetext{
Abstract: Fasting is a biology stress that induce oxidative stress. Oxidative stress reduce spermatogenesis and testis's weight, connected with seminiferous tubules. The aim was to establish the fasting effect on reducing epithelium height and seminiferous tubules diameter of rats. This was a laboratory experimental analytic research, a post-test only with control group design. The research's subjects were 30 male albino rats, wistar strain, 150-300 $\mathrm{g}$ weight, and 2-4 months of age. They were randomly allocated into 3 groups, there were control group, 10 hours and 12 hours fasting group. They were fasting for 14 days. They were terminated, testes were excised and weighed to do histological preparation, and stained with HE. Morfometric analysis used Image J software. Data were analyzed with MANOVA and followed by LSD. The results shows that height of epithelium and seminiferous tubules diameter on fasting group were lower significantly compared with control group $(p<0,05)$. Although, height of epithelium and diameter of seminiferous tubule s on 10 and 12 hours fasting group were not significantly different $(p>0,05)$. We conclude that there was effect of fasting on reducing height of epithelium and diameter of seminiferous tubules of male rats.
} 
Keywords: Stress; Fasting; Epithelium Height; Diameter of Seminiferous Tubules; Rattus norvegicus

\section{PENDAHULUAN}

Stres merupakan respon tubuh yang bersifat nonspesifik terhadap segala ancaman. ${ }^{1}$ Respon tubuh tersebut berupa proses adaptasi yang bertahap dan menimbulkan perubahan fisiologis hingga maladaptif. ${ }^{2}$ Stres berefek buruk terhadap kesehatan pada 43\% orang dewasa. Terdapat 90\% dari semua kunjungan ke dokter merupakan pasien dengan keluhan terkait stres. ${ }^{3}$

Puasa dapat menyebabkan stres oksidatif. Stres oksidatif adalah kondisi terjadinya peningkatan produksi radikal bebas yang dapat menyebabkan kerusakan sel. ${ }^{4}$ Stres oksidatif yang diakibatkan puasa dapat mempengaruhi sistem reproduksi pria. Puasa menurunkan aktivitas spermatogenesis yang dibuktikan dengan penurunan jumlah sperma dan berat testis tikus wistar jantan dewasa. ${ }^{5}$

Puasa akut dan kronik telah banyak diteliti. Namun, puasa subakut durasi <24 jam perhari jarang diteliti, terutama terkait efeknya terhadap tubulus seminiferus. ${ }^{5}$ Penelitian ini berusaha untuk mengetahui efek stres puasa subakut selama 14 hari, dengan durasi <24 jam perhari terhadap ketebalan epitel dan diameter tubulus seminiferus tikus wistar jantan dewasa.

\section{BAHAN DAN CARA}

Penelitian ini merupakan penelitian analitik eksperimental laboratorium dengan pendekatan post-test only with control group design. Subjek penelitian merupakan tikus putih jantan galur wistar sebanyak 30 ekor dengan berat badan 150-300 g, dan umur 2-4 bulan. ${ }^{6,7}$

Subjek penelitian dibagi secara acak menjadi 3 kelompok, yaitu kelompok kontrol, kelompok perlakuan puasa 10 jam, dan kelompok perlakuan puasa 12 jam. Perlakuan puasa diberikan selama 14 hari. Subjek penelitian kemudian diterminasi, dieksisi dan ditimbang testisnya, dilakukan preparasi histologi, dan pewarnaan Hematoxylin Eosin (HE). ${ }^{8}$ Selanjutnya dilakukan analisis morfometrik terhadap ketebalan epitel dan diameter tubulus seminiferus menggunakan perangkat lunak Image $\mathrm{J}^{9}$ Data dianalisis menggunakan Multivariate Analysis of Variance (MANOVA) diikuti uji Least Significant Differences (LSD). ${ }^{10}$

\section{HASIL}

Ketebalan Epitel Tubulus Seminiferus. Ketebalan epitel tubulus seminiferus diukur dengan cara menarik garis dari jarak terdekat pada batas antara lapisan sel spermatogonia hingga permukaan lumen setiap tubulus seminiferus. ${ }^{11}$ Dilakukan 4 kali pengulangan pengukuran ketebalan epitel di tempat yang berbeda pada setiap tubulus seminiferus. Hasil pengukuran ketebalan epitel pada 15 tubulus seminiferus setiap sediaan dirata-rata.

Hasil penelitian menunjukkan rata-rata ketebalan epitel tubulus seminiferus pada kelompok kontrol (Ko) adalah 121,41 $\pm 10,45 \mu \mathrm{m}$, kelompok

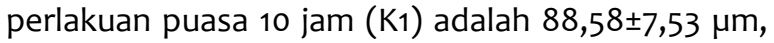
dan kelompok perlakuan puasa 12 jam (K2) adalah $87,61 \pm 8,97 \mu \mathrm{m}$. Data yang diperoleh dilakukan uji homogenitas varian menggunakan uji Levene, dan uji normalitas menggunakan uji Saphiro-Wilk. Hasil uji homogenitas varian dan uji normalitas menunjukkan bahwa seluruh data homogen dan terdistribusi normal $(p>0,05)$. Hal tersebut memenuhi syarat untuk dilakukan uji multivariate analysis of variance (MANOVA).

Hasil uji MANOVA menunjukkan perbedaan signifikan $(p<0,05)$. Hal ini menunjukkan terdapat efek stres puasa terhadap ketebalan epitel tubulus seminiferus pada semua kelompok secara signifikan. Selanjutnya dilakukan uji post hoc menggunakan uji LSD. Hasil uji menunjukkan terdapat perbedaan rata-rata ketebalan epitel tubulus seminiferus yang signifikan $(p<0,05)$ antara kelompok kontrol dan kelompok perlakuan. Namun, rata-rata ketebalan epitel tubulus seminiferus antara kelompok perlakuan puasa 10 jam dan 12 jam tidak terdapat perbedaan yang signifikan $(p>0,05)$. Hal tersebut dapat diamati pada Gambar 1.

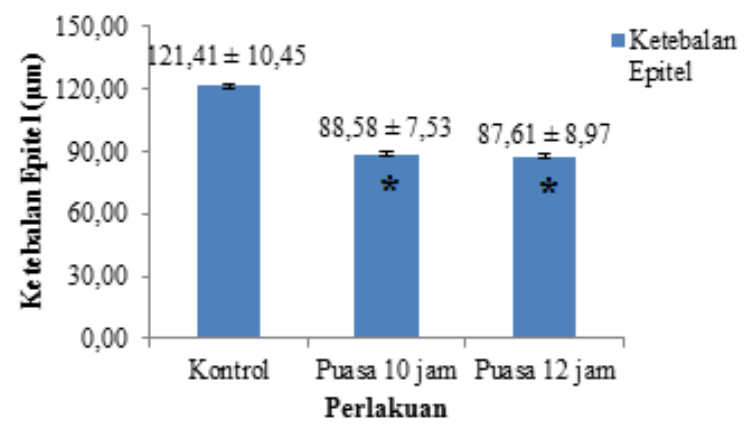

\section{Gambar 1. Rata-rata Ketebalan Epitel Tubulus Seminiferus}

Keterangan: Hasil uji MANOVA $(p=0,000)$ menunjukkan terdapat perbedaan bermakna antarkelompok ${ }^{*} p<0,05$ vs kontrol. Hasil uji post-hoc LSD: kontrol vs puasa 10 jam ( $p=0,000)$, kontrol vs puasa 12 jam $(p=0,000)$, puasa 10 jam vs puasa 12 jam $(p=0,812)$. 


\section{mutiara medika}

Fotomikrograf epitel tubulus seminiferus pada pada Gambar 2. menunjukkan kelompok kontrol tampak tebal dan intak pada membran basalis. Tidak terdapat celah antarsel spermatogenik. Bagian adluminal setiap tubulus seminiferus tampak banyak terdapat spermatozoa. Kelompok perlakuan puasa 10 jam menunjukkan terdapat 2 tubulus seminiferus yang epitelnya terlepas dari membran basalis. Spermatozoa pada bagian adluminal tubulus seminiferus yang tidak intak tampak lebih sedikit. Kelompok perlakuan puasa 12 jam menunjukkan epitel pada hampir seluruh tubulus seminiferus tidak intak antarsel spermatogenik. Spermatozoa pada bagian adluminal beberapa tubulus seminiferus tampak lebih sedikit.

Hasil histomorfometri menggunakan perangkat lunak Image $J$ menunjukkan ketebalan epitel pada salah satu tubulus seminiferus kelompok kontrol adalah 177,21 $\mu \mathrm{m}$. Ketebalan epitel salah satu tubulus seminiferus pada kelompok perlakuan puasa 10 jam adalah 118,21 $\mu \mathrm{m}$, sedangkan ketebalan epitel salah satu tubulus seminiferus pada kelompok perlakuan puasa 12 jam adalah 101,45 $\mu \mathrm{m}$.

Diameter Tubulus Seminiferus. Diameter tubulus seminiferus merupakan garis tengah tubulus seminiferus yang bulat atau hampir bulat. Dilakukan 2 kali pengulangan pengukuran diameter setiap tubulus seminiferus. Pengukuran dilakukan dengan cara menarik garis pada jarak terpendek dan terpanjang yang menghubungkan garis tepi terluar tubulus seminiferus. ${ }^{8,12}$

Hasil pengukuran diameter pada 15 tubulus seminiferus setiap sediaan selanjutnya dirata-rata. Rata-rata diameter tubulus seminiferus pada kelompok kontrol (Ko) adalah 450,24 $\pm 28,68 \mu \mathrm{m}$, kelompok perlakuan puasa 10 jam (K1) adalah $417,01 \pm 27,90 \mu \mathrm{m}$ dan kelompok perlakuan puasa 12 jam (K2) adalah 406,53 $\pm 35,58 \mu \mathrm{m}$.

Data yang diperoleh dilakukan uji homogenitas varian menggunakan uji Levene, dan uji normalitas menggunakan uji Saphiro-Wilk. Hasil uji homogenitas varian dan uji normalitas menunjukkan bahwa
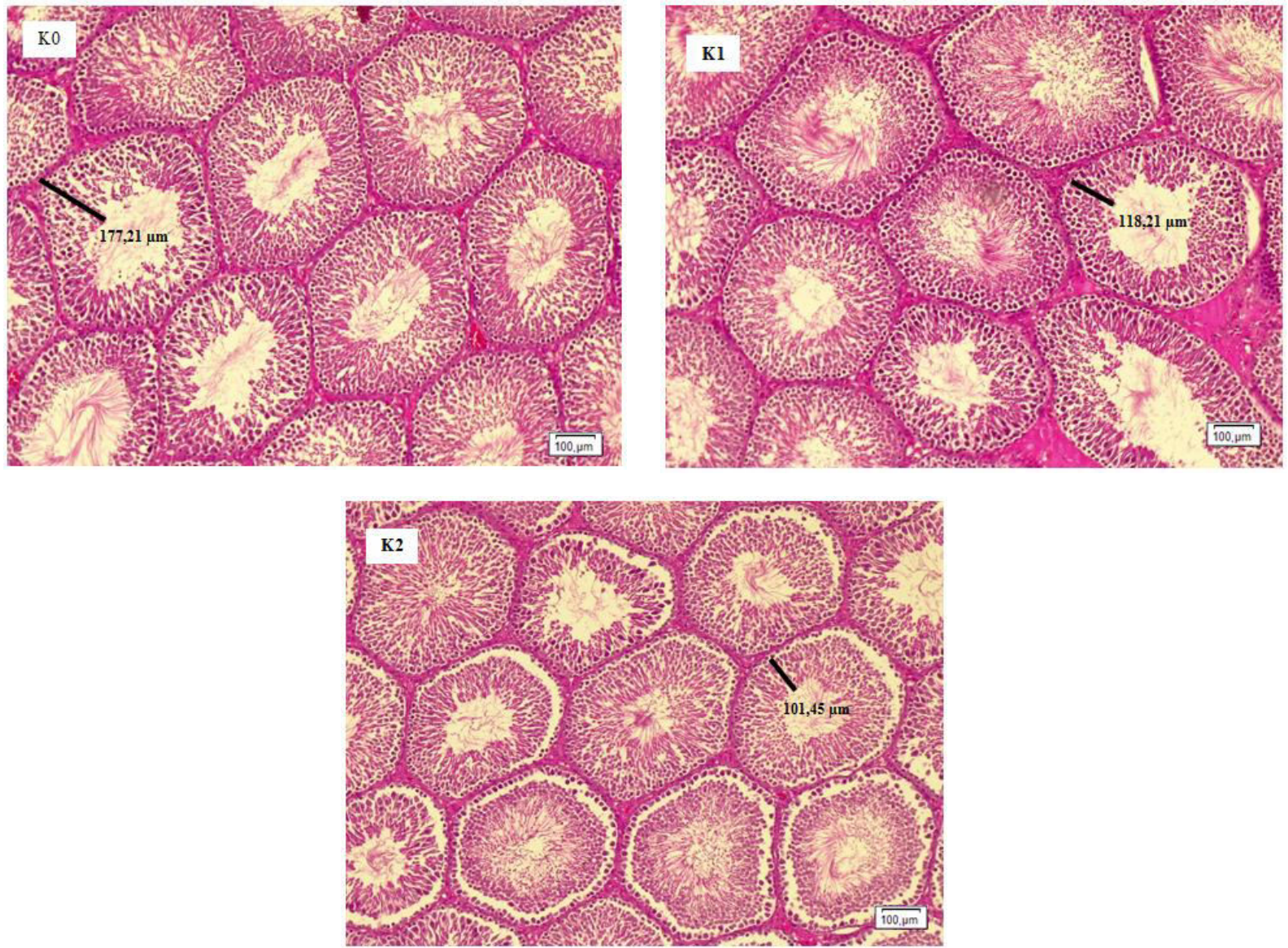

Gambar 2. Fotomikrograf Tubulus Seminiferus Kelompok Kontrol (Ko), Puasa 10 Jam (K1) dan Puasa 12 Jam (K2) Perbesaran 100x dengan Pewarnaan HE

Keterangan: Garis hitam menunjukkan ketebalan epitel tubulus seminiferus dan keterangan ukurannya. 

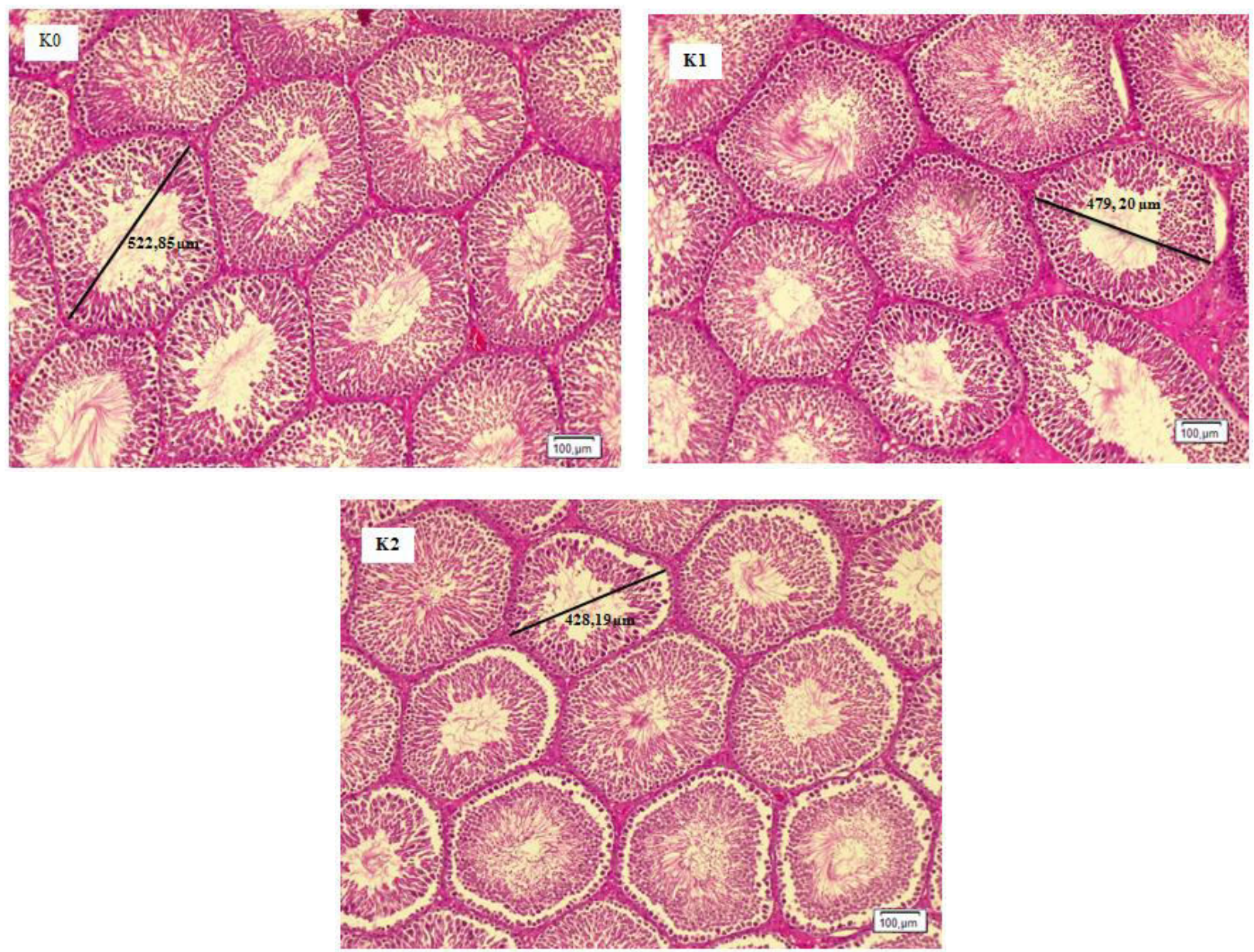

\section{Gambar 4. Fotomikrograf Tubulus Seminiferus Kelompok Kontrol (Ko), Puasa 10 Jam (K1), dan Puasa 12 Jam (K2) Perbesaran 100x dengan Pewarnaan HE}

Keterangan: Garis hitam menunjukkan diameter tubulus seminiferus dan keterangan ukurannya.

seluruh data homogen dan terdistribusi normal $(p>0,05)$. Hasil uji MANOVA menunjukkan terdapat efek stres puasa terhadap diameter tubulus seminiferus pada semua kelompok secara signifikan $(p<0,05)$. Uji post hoc menggunakan uji LSD menunjukkan terdapat perbedaan rata-rata diameter tubulus seminiferus yang signifikan $(p<0,05)$ antara kelompok kontrol dan kelompok perlakuan. Namun demikian, rata-rata diameter tubulus semi-niferus antara kelompok perlakuan puasa 10 jam dan 12 jam tidak terdapat perbedaan secara signifikan $(p>0.05)$. Hal tersebut dapat diamati di Gambar 3 .

Fotomikrograf tubulus seminiferus yang ditunjukkan pada Gambar 4. menunjukkan perbedaan diameter tubulus seminiferus pada masingmasing kelompok. Pengamatan histopatologi diameter tubulus seminiferus pada kelompok kontrol tampak berukuran besar. Berbeda dengan kelompok perlakuan puasa $10 \mathrm{jam}$, ukuran diameter pada beberapa tubulus seminiferus tampak sempit. Kelompok perlakuan puasa 12 jam memiliki ukuran diameter yang sempit pada setiap tubulus seminiferus.

Hasil histomorfometri menggunakan perangkat lunak Image J pada Gambar 4. yang ditunjukkan dengan garis hitam merupakan ukuran diameter pada salah satu tubulus seminiferus. Diameter kelompok kontrol (Ko) adalah 522,85 $\mu \mathrm{m}$, kelompok perlakuan puasa 10 jam (K1) adalah 479,20 $\mu \mathrm{m}$, dan pada kelompok perlakuan puasa $12 \mathrm{jam}(\mathrm{K} 2)$ adalah $428,19 \mu \mathrm{m}$.

\section{DISKUSI}

Hasil pengukuran rata-rata ketebalan epitel tubulus seminiferus pada kelompok perlakuan puasa 10 jam dan 12 jam lebih rendah dibandingkan dengan kelompok kontrol. Hasil pengamatan histopatologi menunjukkan bagian adluminal pada kelompok kontrol tampak sel spermatozoa yang lebih banyak pada setiap tubulus seminiferus dibandingkan dengan kelompok perlakuan puasa 10 jam dan 12 jam. Epitel tubulus seminiferus pada 


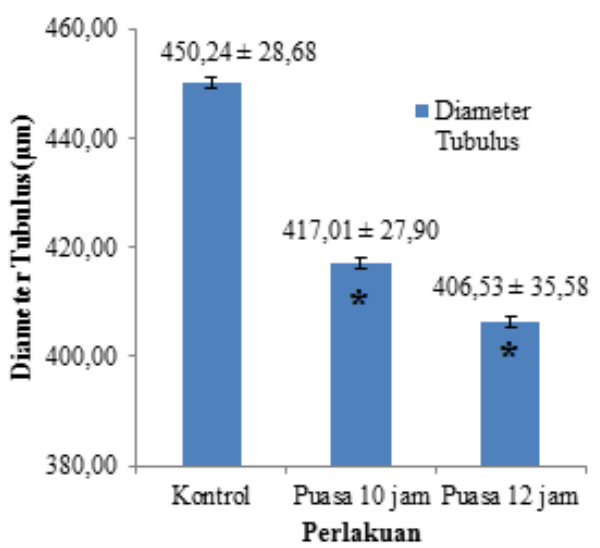

Gambar 3. Rata-rata Diameter Tubulus Seminiferus Kelompok Kontrol (Ko), Puasa 10 Jam (K1) dan Puasa 12 Jam (K2)

kelompok kontrol lebih intak antarsel spermatogenik maupun antara membran basalis dengan sel spermatogenik. Sel spermatogenik yang tidak intak antarselnya maupun dengan membran basalis menyebabkan hasil pengukuran histomorfometri ketebalan epitel tubulus seminiferus pada kelompok perlakuan puasa 10 jam dan 12 jam lebih rendah dibandingkan kelompok kontrol.

Rata-rata diameter tubulus seminiferus pada kelompok perlakuan puasa 10 jam dan 12 jam lebih rendah dibandingkan dengan kelompok kontrol. Hasil pengamatan histopatologi diameter tubulus seminiferus pada kelompok kontrol tampak lebih besar dibandingkan dengan kelompok perlakuan puasa $10 \mathrm{jam}$ dan $12 \mathrm{jam}$. Hal tersebut terbukti pada pengukuran histomorfometri diameter tubulus seminiferus yang menunjukkan bahwa diameter tubulus seminiferus pada kelompok perlakuan puasa 10 jam dan 12 jam lebih rendah dibandingkan kelompok kontrol.

Hasil penelitian ini menunjukkan stres puasa berefek terhadap ketebalan epitel dan diameter tubulus seminiferus. Pembatasan kalori tingkat rendah pada puasa mengakibatkan atrofi tubulus seminiferus dan penurunan diameter tubulus seminiferus. ${ }^{8}$ Hal tersebut terjadi karena adanya penurunan jumlah sel spermatosit dan sel spermatid yang mengisi epitel tubulus seminiferus. ${ }^{13}$

Pembatasan akses terhadap nutrisi dapat menurunkan ketebalan epitel dan diameter tubulus seminiferus testis. Kurangnya asupan protein menunjukkan seluruh tubulus seminiferus pada kelompok perlakuan memiliki lumen yang luas dan epitel yang tipis dibandingkan dengan kelompok kontrol pada histopatologi dan histomorfometri testis tikus wistar. Hal ini terjadi karena protein sangat penting dalam mengangkut testosteron masuk ke dalam lumen tubulus seminiferus untuk berlangsungnya spermatogenesis sehingga menghambat maturasi, pertumbuhan dan fungsi organ reproduksi. $14,15,16$

Puasa dapat menimbulkan stres oksidatif. Stres oksidatif menunjukkan adanya ketidakseimbangan antara prooksidan dan antioksidan dalam tubuh. ${ }^{17}$ Hal ini ditandai dengan adanya peningkatan produksi radikal bebas berupa reactive oxygen species (ROS) yang dapat menyebabkan kerusakan sel. ${ }^{4}$ Peningkatan ROS pada testis menyebabkan apoptosis sel spermatogenik yang terjadi melalui proses peroksidasi lipid. ${ }^{17}$

Peroksidasi lipid terjadi karena spermatozoa sangat rentan terhadap stres oksidatif. Kerentanan ini terutama disebabkan oleh membran selnya yang banyak mengandung asam lemak tak jenuh ganda yang disebut polyunsaturated fatty acids (PUFAs). Selain itu, membran plasma spermatozoa juga rusak akibat kegagalan fusi spermatosit. Ketidakmampuan spermatozoa untuk mengembalikan kerusakan akibat stres oksidatif karena kurangnya sistem perbaikan pada enzim sitoplasmanya juga turut berperan dalam proses ini. ${ }^{18}$ Hal tersebut menjelaskan bahwa puasa intermiten seperti pada penelitian kali ini meningkatkan stres oksidatif yang menyebabkan kerusakan sperma pada tubulus seminiferus. ${ }^{19,20,21}$

Puasa merupakan jenis stres biologi. Stres biologi yang ditimbulkan oleh puasa dapat menurunkan ketebalan epitel dan diameter tubulus seminiferus. ${ }^{22}$ Hal tersebut terjadi karena produksi stres oksidatif pada testis. ${ }^{23}$ Stres oksidatif menyebabkan kerusakan deoxyribonucleic acid (DNA), protein, dan glukosa. Akibatnya, adenosine triphosphate (ATP) intraseluler hilang dengan cepat. ${ }^{24} \mathrm{Hal}$ ini menyebabkan kondisi hipoglikemik sel yang mempengaruhi hormon seks. ${ }^{25,26}$ Kelebihan atau kekurangan produksi hormon dapat menyebabkan apoptosis sel testis. ${ }^{27}$ Hormon seks yang dipengaruhi adalah testosteron yang berfungsi dalam spermatogenesis. ${ }^{16}$

Produksi testosteron oleh sel leydig terhambat karena ROS mempengaruhi transfer kolesterol pada mitokondria. Hal ini dikarenakan mitokondria merupakan tempat produksi utama dari ROS endogen. Terjadi Proses apoptosis terjadi karena stres intraseluler menginduksi produksi sitokrom c. Sitokrom c meningkatkan permeabilitas membran luar mitokondria. Hal ini menstimulasi difusi protein apoptotik menuju sitosol. Interaksi antara sitokrom c dan protein apoptotik menyebabkan terbentuknya apoptosom. Apoptosom mengaktivasi caspase, sistein protease yang menginduksi apoptosis. ${ }^{28}$ 
Tubulus seminiferus terdiri dari sel spermatogenik dan sel sertoli. Sel spermatogenik terbentuk melalui proses spermatogenesis. Sel sertoli berfungsi sebagai penunjang, diantaranya menjaga ikatan antarsel sertoli, dengan sel spermatogenik, atau antarsel spermatogenik untuk membentuk sawar darah testis. ${ }^{15,16}$ Sawar darah testis berfungsi meregulasi nutrisi dan faktor pertumbuhan untuk perkembangan sel spermatogenik. ${ }^{23}$

Tampak pada fotomikrograf tubulus seminiferus, epitel pada kelompok perlakuan tidak intak satu sama lain. Hal ini disebabkan karena stres oksidatif merusak taut dan adesi antarsel sertoli, sel sertoli dengan sel spermatogenik dan antar sel spermatogenik. Mekanisme yang terjadi adalah melalui aktivasi sinyal phosphatidylinositol 3-kinase (PI3K)-focal adhesion kinase (FAK). Phosphatidylinositol 3-kinase yang semula terdapat pada sitosol mengalami translokasi menuju membran sel yang akan meningkatkan permeabilitas membran sel epitel dan sel endotel. Focal adhesion kinase berperan sebagai mediator dalam proses ini. ${ }^{29}$ Selain itu, dikarenakan taut antarsel sertoli rusak, maka terjadi kekurangan nutrisi dan faktor pertumbuhan bagi perkembangan sel spermatogenik. ${ }^{23}$

Berkurangnya spermatozoa pada bagian adluminal tubulus seminiferus terjadi karena penurunan glukosa dalam tubuh. Hal ini mengubah aksis kelenjar hipotalamus-hipofisis-testis yang menurunkan spermatogenesis. ${ }^{5}$ Akibatnya, terjadi penurunan berat testis. ${ }^{30}$ Perubahan berat testis dapat merefleksikan perubahan pada tubulus seminiferus yang mengisi $80 \%$ massa testis. ${ }^{16}$

\section{SIMPULAN}

Terdapat penurunan ketebalan epitel dan diameter tubulus seminiferus tikus wistar jantan dewasa pada perlakuan puasa dibandingkan dengan kelompok kontrol.

\section{DAFTAR PUSTAKA}

1. Kalat, JW. Introduction to Psychology $\left(10^{\text {th }}\right.$ Edition). Belmont: Wadsworth. 2013.

2. Pinel, JPJ. Biopsikologi (Edisi ke- 7). Yogyakarta: Pustaka Pelajar. 2012.

3. Taufiqurrohman. Berdamai dengan Stres. Yogyakarta: Pusat Ilmu. 2015.

4. Suarsana, IN., Wresdiyati, T. dan Suprayogi, A. Respon Stres Oksidatif dan Pemberian Isoflavon terhadap Aktivitas Enzim Superoksida Dismutase dan Peroksidasi Lipid pada Hati Tikus. Jurnal Ilmu Ternak dan Veteriner, 2013; 18 (2): 146-152.
5. Omolaso, BO., Akanbi CO., Akintayo, CO. dan Oluwole, FS. Evaluation of the Effects of Fasting on Fertility in Adult Male Wistar Rats. IOSR J Pharm Biol Scie. 2012; 3 (4): 12-15.

6. Fitria, L., Mulyati., Tiraya, C.M. dan Budi, A.S. Profil Reproduksi Jantan Tikus (Rattus norvegicus Berkenhout, 1769) Galur Wistar Stadia Muda, Pradewasa dan Dewasa. Jurnal Biologi Papua, 2015; 7 (1): 29-36.

7. Tahtamouni, LH., Mustafa, NH., Hassan, IM., Ahmad, IM., Yasin, SR. dan Abdalla, MY. Nandrolone Decanoate Administration to Male Rats Induces Oxidative Stress, Seminiferous Tubules Abnormalities and Sperm DNA Fragmentation. Jordan Journal of Biological Sciences, 2010; 3 (4): 165-174.

8. Rocha, JS., Bordoni, LS. dan Franca, LR. Effects of Mild Calorie Restriction on Reproductive Parameters of Pubertal and Sexually Mature Male Wistar Rats. Anim Reprod Scie, 2012; 9 (2): 93-102.

9. Kurniawan, C., Waluyo, TB., dan Sebayang, P. Analisis Ukuran Partikel Menggunakan Free Software Image-J. Seminar Nasional Fisika 2011 Pusat Penelitian Fisika-LIPI. 2011.

10. Dahlan, S. Langkah-langkah Membuat Proposal Penelitian Bidang Kedokteran dan Kesehatan (Edisi ke-2). Jakarta: Sagung Seto. 2014.

11. Purwoistri, RF. Pengaruh Ekstrak Biji Pepaya (Carica papaya L.) terhadap Spermatogenesis dan Tebal Epitel Tubulus Seminiferus Testis Mencit (Mus musculus) Jantan. Skripsi. Fakultas Sains dan Teknologi Universitas Islam Negeri Maulana Malik Ibrahim Malang. 2010.

12. Zhe, L., Qing, C., Zeng-lu, X. dan Zheng-guo, Z. Stereological Measurement of Rat's Seminiferous Tubule. Chin Med J, 2009; 122 (21): 2643-2646.

13. Apriliani, M., Nurcahayani, N. dan Busman, H. Efek Pemaparan Kebisingan terhadap Jumlah Selsel Spermatogenik dan Diameter Tubulus Seminiferus Mencit (Mus musculus L.). Lembaga Penelitian Universitas Lampung. 2013.

14. Ozegbe, P.C. dan Omirinde, J.O. Comparative Morphophysiological Evaluation of the Testis of Adult Wistar Rats Fed Low Protein-Energy Diet and Dosed with Aqueous Extracts of Cuscuta australis. Niger J Physiol Sci, 2012; 27 (2): 149-155.

15. Mescher, A.L. Histologi Dasar Junqueira (Edisi ke12). Jakarta: EGC. 2012.

16. Sherwood, L. Fisiologi Manusia: dari Sel ke Sistem (Edisi ke-6). Jakarta: EGC. 2012.

17. Sulistyoningrum, E., Setiawati., Nindyastuti, H. dan Putra, A.N. Infusa Daging Buah Mahkota Dewa Memperbaiki Kerusakan Testis dan Parameter Sperma Tikus Diabetik. Jurnal Sains Medika, 2012; 4 (2): 115-123. 
18. Agarwal, A., Virk, G., Ong, C. dan Plessis, S. S.D. Effect of Oxidative Stress on Male Reproduction. World J Mens Health, 2014; 32 (1): 1-17.

19. Faris, MA., Hussein, RN., Al-Kurd, RA., AlFararjeh, MA., Bustanji, YK. dan Mohammad, MK. Impact of Ramadan Intermittent Fasting on Oxidative Stress Measured by Urinary $15-\mathrm{F}_{2 \mathrm{\tau}}$ Isoprostane. J Nutr Metab, 2012; 1-10.

20. Katib, A. Mechanisms Linking Obesity to Male Infertility. Cent European J Urol, 2015; 68 (1): 79 . 85.

21. Hamada, A., Esteves, SC., Nizza, M. dan Agarwal, A. Unexplained Male Infertility: Diagnosis and Management. Int Braz J Urol, 2012; 38 (5): 576 594.

22. Indriana, Y., Kristiana, IF., Sonda, AA., dan Intanirian, A. Tingkat Stres Lansia di Panti Wredha "Pucang Gading" Semarang. Jurnal Psikologi Undip, 2010; 8 (2): 87-96.

23. Mathur, PP. dan D'Cruz, SC. The Effect of Environmental Contaminants on Testicular Function. Asian J Androl, 2011; 13 (4): 585-591.

24. Taib, IS., Budin, SB., Ghazali, AR., Jayusmas, PA., Louis, SR., dan Mohamed, J. Fenitrothion Induced Oxidative Stress and Morphological
Alterations of Sperm and Testes in Male Spraguedawley Rats. Clinics, 2012; 68 (1): 93-100.

25. Guilliams, TG. dan Edwards, L. Chronic Stress and The HPA Axis: Clinical Assessment and the Therapeutic Considerations. Point Institute of Nutraceutical Research, 2010; 9 (2): 1-12.

26. Boroumand, N., dan Hashemy, S. I. The Effect of Ramadan Fasting on Endocrine System. Journal of Fasting and Health, 2015; 3 (4): 148-155.

27. Shaha, C., Tripathi, R. dan Mishra, DP. Male Germ Cell Apoptosis: Regulation and Biology. Philos Trans R Soc Lond B Biol Sci, 2010; 365 (1546): 1501-1515.

28. Mathur, PP., Huang, L., Kashou, A., Vaithanathan, S. dan Agarwal, A. Environmental Toxicants and Testicular Apoptosis. The Open Reproductive Sci J, 2011; 3: 114-124.

29. Wong, EWP. dan Cheng, CY. Impacts of Environmental Toxicants on Male Reproductive Dysfunction. Trends in Pharmacol Sci J, 2011; 32 (5): 290-299.

30. Kavak, V., Balsak, D., Togrul, C., Deveci, E., Ekinci, A., Ekinci, C., et al. The Effects of Maternal Low Protein and Estrogen on Sexual Behavior and Testicular Maturation in Male Rats. Int J Morphol, 2015; 33 (1): 204-209. 